\title{
Evaluation of the Chemical and Bacteriological Quality of Bagged Water in Ivory Coast (Seven Localities)
}

\author{
Kouadio Enika Floresse*, N'goran-Aw E. B. Zita, Soro Doudjo \\ and ASSIDJO Nogbou Emmanue
}

Institut National Polytechnique Felix Houphouët Boigny (INP-HB), Yamoussoukro, Cote 'Ivoire, Agri-Food Chemistry Group Laboratory - BP 1093 Yamoussoukro - Cote 'Ivoire

*Corresponding author

\section{A B S T R A C T}

\begin{tabular}{|l|}
\hline Ke y w or d s \\
Evaluation, Quality, \\
Bagged water, \\
Health risks
\end{tabular}

The aim of this study is to assess the physico-chemical and microbiological quality of water packaged in an industrial way and those packaged in a traditional way in order to understand the risks of exposure of the consumer population. To achieve this objective, a survey was carried out among 600 people. 270 samples of bagged water were collected in seven localities in Côte d'Ivoire. Then, physico-chemical and microbiological analyses of the samples were carried out to determine the quality of the water. It emerges from this work that the majority of the $\mathrm{pH}$ of the water packaged in bags in these localities are acidic. The temperatures of the packaged waters vary between 13.6 and $22.6^{\circ} \mathrm{C}$. The levels of residual chlorine recorded in the conditioned waters of the cities studied do not comply with the limit value recommended by the WHO, which is around $0.2 \mathrm{mg} / \mathrm{L}$. Concerning the microbiological quality of the bagged water, the analyses revealed the presence of mesophilic aerobic germs, Total Coliforms and Escherichia Coli. Waters packaged in an artisanal and industrial way are not of good quality from a bacteriological point of view.

\section{Introduction}

The importance of water is preponderant, like other indispensable elements in human life, both for its consumption and for its physiological needs (UN, 2019). Indeed, humans can refuse to eat food, but they cannot go more than three days without drinking water (Akiyo, 2017). Water is an element in promoting the health of living beings and the socio-economic development of human communities. Consumption of poor quality water would then constitute an assault on the life of the consumer. It is for this reason that the quality of drinking water appears to be an issue of concern throughout the world (WHO, 2011; El Haissoufi et al., 2011)

In recent years, in Côte d'Ivoire, the marketing of bagged water has become an activity that offers several significant socioeconomic opportunities to the population (Ble et al., 2015). These waters are conditioned in an artisanal way in households or in an industrial way in semi-industrial companies. 
Like manufactured products, water packaged in sachets seems to have the consent of many consumers (Ble et al., 2009). This is because they are convenient, refreshing and in expensive for low-income residents. Increasingly, however, the quality of bagged water is being questioned on both sides for a number of reasons.

\section{Is the conditioned water drinkable?}

Does the quality of industrially packaged water in bags differ from that of artisanal bottled water?

Does the quality of industrially packaged water in bags differ from that of artisanal bottled water?

It is to answer these concerns that this study aims to assess the physico-chemical and microbiological quality of water packaged in an industrial way and those packaged in an artisanal way in order to apprehend the risks of exposure of the consumer population.

\section{Materials and Methods}

\section{Presentation of the Study Area}

The quality of the bagged water discussed in this study was observed in some localities in Côte d'Ivoire. These localities were selected in the main regions: Abidjan (South), Abengourou (South-East), Bouaké (Centre), Korhogo (North), Daloa (Centre-West), de Man (West) and San-Pedro (South-West). In these areas, there is a diversity of packaged waters that are sold (Figure 1).

\section{Investigations}

A investigation took place from December 22, 2017 to August 28, 2018 in seven localities in Côte d'Ivoire to find out the types of water sachets consumed, the conditions of water bagging and the water used for packaging. To this end, a semi-directive questionnaire was developed based on a qualitative analysis of the population.

\section{Sampling}

The sampling campaign was conducted from January 17 to May 28, 2018. A total of 270 sachets of artisanally and industrially packaged water were collected. 210 sachets were collected in Korhogo, Bouaké, Daloa, Man, Abengourou and San-Pedro with 30 sachets per city. 60 sachets were collected in Abidjan. They were collected with vendors in bus stations, stores and near public roads. They were then placed in coolers containing ice to maintain temperatures at $4^{\circ} \mathrm{C}$ until the laboratory.

\section{Physical and chemical analyses}

The $\mathrm{pH}$, temperature and conductivity were determined using a HACH44600 portable multimeter according to the techniques of Rodier et al (2009). Turbidity was measured with a HACH 2100P turbidimeter according to Rodier et al., (2009).

Residual chlorine was measured with a LOVIBOND MD200 colorimeter (SODIMEL, France) with diethyl paraphenyl diamine (DPD) pellet (reagent).

Nitrate was determined according to $\mathrm{HACH}$ methods with the UV / visible Spectrophotometer DR $6000 \mathrm{HACH}$ (SODIMEL, France).

\section{Microbiological analyses}

Mesophilic aerobic germ count was performed on Plate Count Agar (PCA,) (Difco) and incubated at $37^{\circ} \mathrm{C}$ for 24 hours. Total coliforms and Escherichia coli were enumerated on crystal violet and neutral red 
(VBRL,) and TBX biliated lactose media according to ISO 9308-1:2014.

Salmonella was tested on Hektoen gelose according to the ISO 6579 (2002) method, following: pre-enrichment, enrichment, isolation and identification.

\section{Statistical analysis}

The histograms were obtained based on mean values and standard deviations using the Excel 2013 analysis utility. The mean values of the artisanal and industrial bagged water were compared using an analysis of variance (ANOVA) with a factor at the significance threshold set at $p=0.05$. XLSTAT software was used to process the data.

\section{Results and Discussion}

\section{Survey results}

Figure 2 shows the proportions of water conditioned in an artisanal and industrial way. $70.31 \%$ of the population surveyed consume industrially packaged water. In contrast, $29.68 \%$ of the population surveyed in these localities consume water packaged in an artisanal manner. Industrially packaged water is consumed more than artisanal water. According to the population, industrially packaged water is more available and more hygienic than artisanal water. According to Kouadio et al., (2013) semi-industrial water is more accessible and less contaminated than artisanal water.

\section{pH of bagged water}

The average $\mathrm{pH}$ values of artisanally packaged waters vary between $5.8 \pm 0.57$ and $7.2 \pm 0.54$. For industrially packaged water, the $\mathrm{pH}$ values range from $5.8 \pm 0.48$ to $6.8 \pm$ 0.69 . The results of the analyses reveal that there is no significant difference between the
$\mathrm{pH}$ of waters conditioned in an artisanal and industrial way. This shows that the waters packaged in an artisanal and industrial way could come from the same source.

The $\mathrm{pH}$ values of these waters are between 5.8 and 7.2 and most of them are below 7 . This shows the acidity of these waters. This acidity could be related either to the types of rocks crossed by these waters or to the types of treatment adopted. The work ofAhoussi et al., (2018) and MBraet al., (2015) carried out on groundwater in some regions of Côte d'Ivoire, revealed the acidity of these waters.

\section{Turbidity of bagged water}

The average turbidity concentrations of bagged water range from $1.3 \pm 0.17$ to $2.8 \pm$ $0.24 \mathrm{NTU}$. The figure shows that there is a significant difference between the turbidity values of artisanal and industrial packaged water in the cities of Korhogo, Bouaké, Daloa and Abidjan. The average turbidity values of bagged water are less than 1 NTU which is recommended by the WHO for drinking water. This difference could be justified by the type of treatment adopted during water conditioning. According Blé et al., (2015), some people use filters during conditioning while.Otcher do not use filters. This is because filters can retain suspended solid.

\section{Température of the water in the bag}

The average temperature values of the conditioned water vary between $13.6 \pm 0.89$ and $22.5 \pm 1.45^{\circ} \mathrm{C}$. They reveal that there is a significant difference between the temperatures of water conditioned in the artisanal and industrial way in the cities of Korhogo, Daloa, San -Pedro. The majority of the temperatures of these waters comply with the value recommended by the WHO, which is $22^{\circ} \mathrm{C}$ for drinking water. 
Table.1 Bacterial loads of water packaged in sachets in an artisanal way

\begin{tabular}{|l|c|c|c|c|}
\hline Sample city & $\begin{array}{c}\text { Germes aérobies } \\
\text { mésophiles }\end{array}$ & $\begin{array}{c}\text { Coliformes } \\
\text { totaux } \\
\text { (UFC/100mL) }\end{array}$ & $\begin{array}{c}\text { Escherichia Coli } \\
(\text { UFC/100 } \mathbf{m L})\end{array}$ & $\begin{array}{c}\text { Salmonella } \\
(\mathbf{1 0 0} \mathbf{m L})\end{array}$ \\
\hline Korhogo & $542 \pm 19$ & $510 \pm 26$ & 0 & Absence \\
\hline Bouaké & $712 \pm 18$ & $414 \pm 12$ & $90 \pm 28$ & Absence \\
\hline Daloa & $528 \pm 15$ & $621 \pm 14$ & $485 \pm 10$ & Absence \\
\hline Man & $485 \pm 14$ & $451 \pm 12$ & - & Absence \\
\hline Abengourou & $451 \pm 17$ & $451 \pm 18$ & - & Absence \\
\hline San Pedro & $556 \pm 24$ & $458 \pm 12$ & $490 \pm 25$ & absence \\
\hline Abidjan & $545 \pm 18$ & $451 \pm 12$ & - & absence \\
\hline $\begin{array}{l}\text { Level of } \\
\text { contamination n } \mathbf{( \% )}\end{array}$ & 19,99 & 17,61 & 4,76 & 0 \\
\hline
\end{tabular}

Table.2 Bacterial load of industrially packaged water

\begin{tabular}{|l|c|c|c|c|}
\hline Sample city & $\begin{array}{c}\text { Germes aérobies } \\
\text { mésophiles }\end{array}$ & $\begin{array}{c}\text { Coliformes } \\
\text { totaux } \\
\text { (UFC/100mL) }\end{array}$ & $\begin{array}{c}\text { Escherichia } \\
\text { coli }(\mathbf{U F C / 1 0 0} \\
\mathbf{m L})\end{array}$ & Salmonella (100 $\mathbf{m L )}$ \\
\hline Korhogo & $369 \pm 13$ & $420 \pm 18$ & $684 \pm 22$ & Absence \\
\hline Bouaké & $418 \pm 15$ & $185 \pm 24$ & - & Absence \\
\hline Daloa & $398 \pm 18$ & - & - & Absence \\
\hline Man & $189 \pm 16$ & $212 \pm 15$ & - & Absence \\
\hline Abengourou & $289 \pm 21$ & & - & Absence \\
\hline San Pedro & $389 \pm 14$ & $471 \pm 17$ & $502 \pm 17$ & Absence \\
\hline Abidjan & $186 \pm 19$ & $147 \pm 14,5$ & - & Absence \\
\hline $\begin{array}{l}\text { Level of } \\
\text { contamination }(\%)\end{array}$ & 14,28 & 9,04 & 3,32 & \\
\hline
\end{tabular}

Fig.1 Study areas of 7 localities of the Ivory Coast

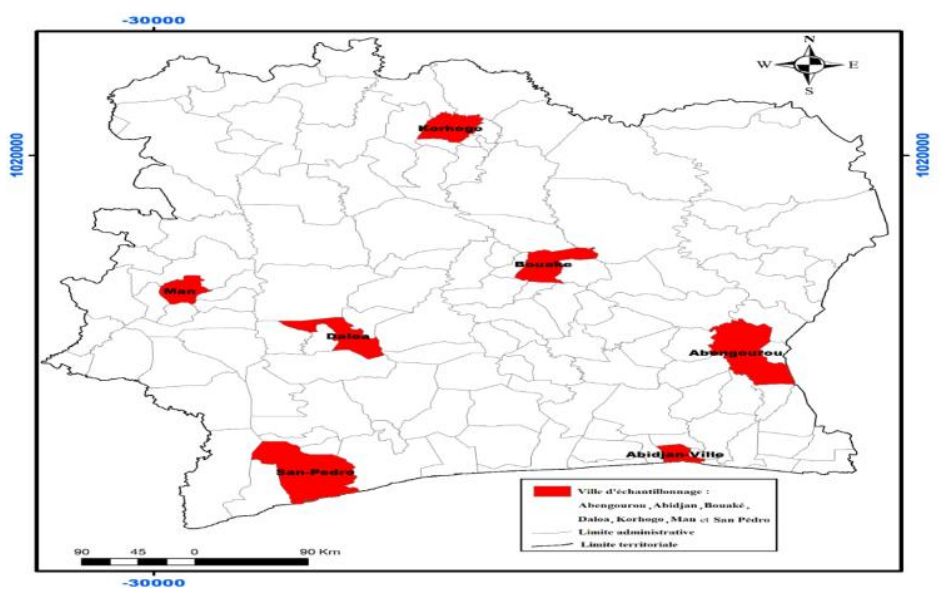


Fig.2 Proportion of consumption of packaged water

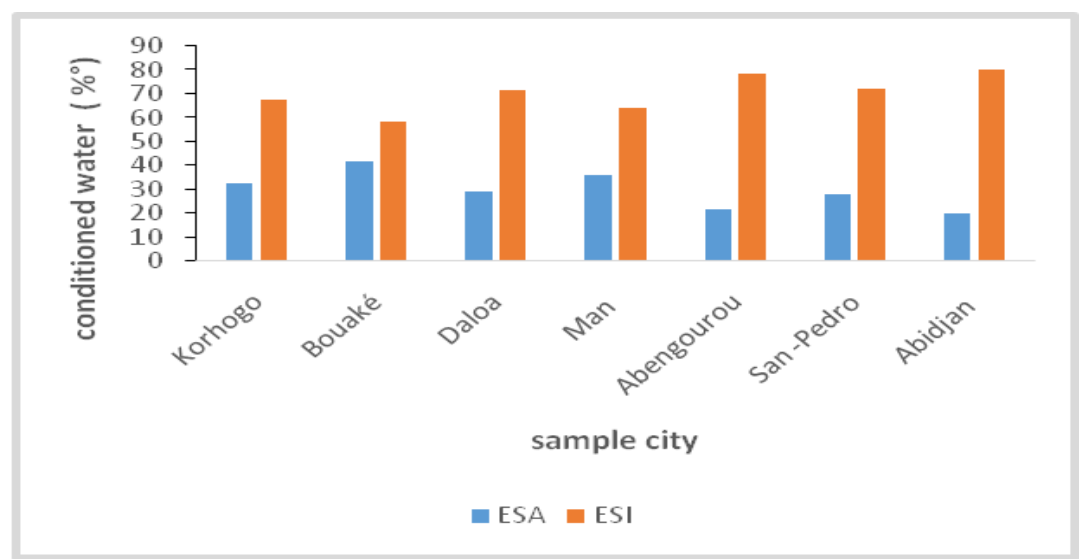

ESI : Industrially packacger water

ESA : Artisanally packager water

Fig.3 pH of waters conditioned in an artisanal and industrial

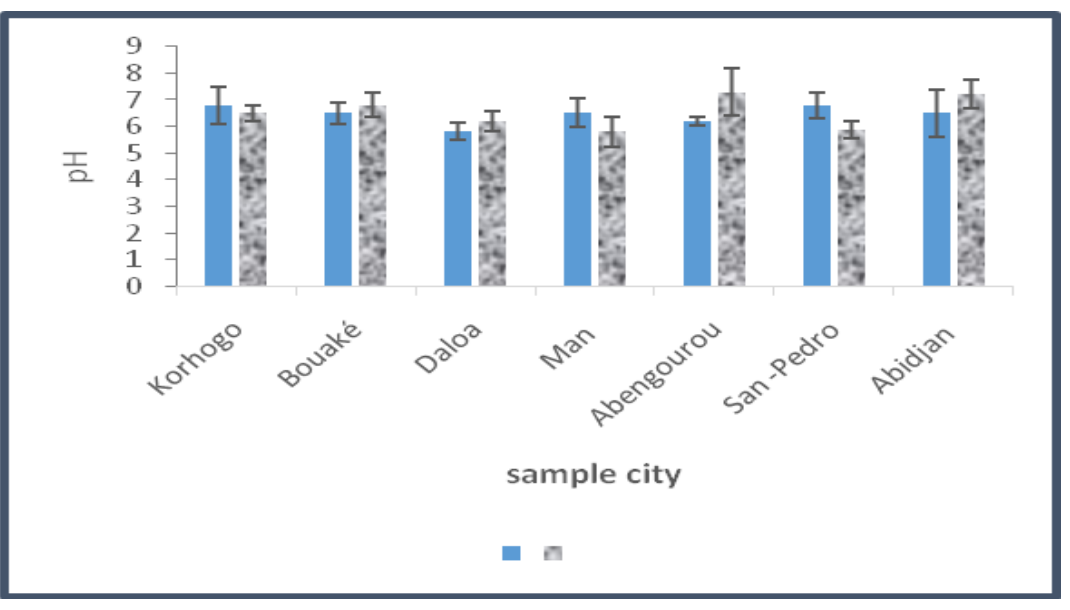

Fig.4 Turbidity of water conditioned in an artisanal and industrial way

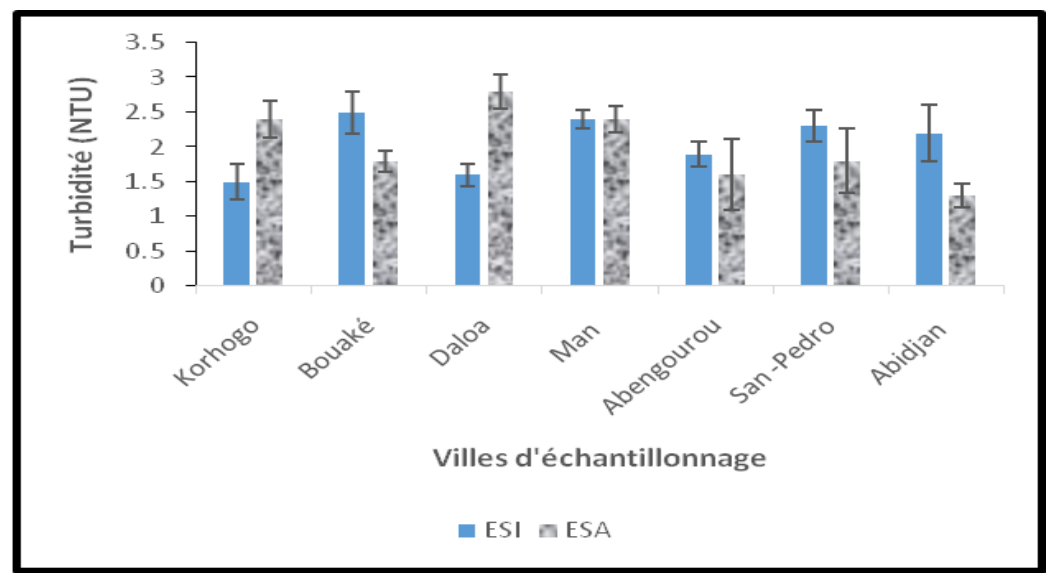


Fig.5 Temperature of artisanal and industrial packaged water

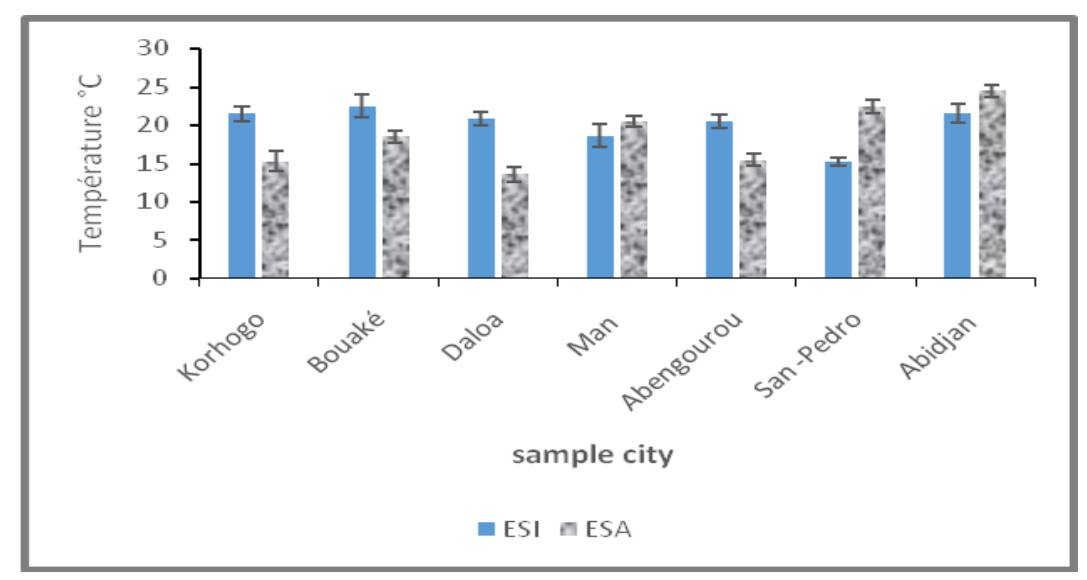

Fig.6 Residual chlorine from water conditioned in an artisanal and industrial manner

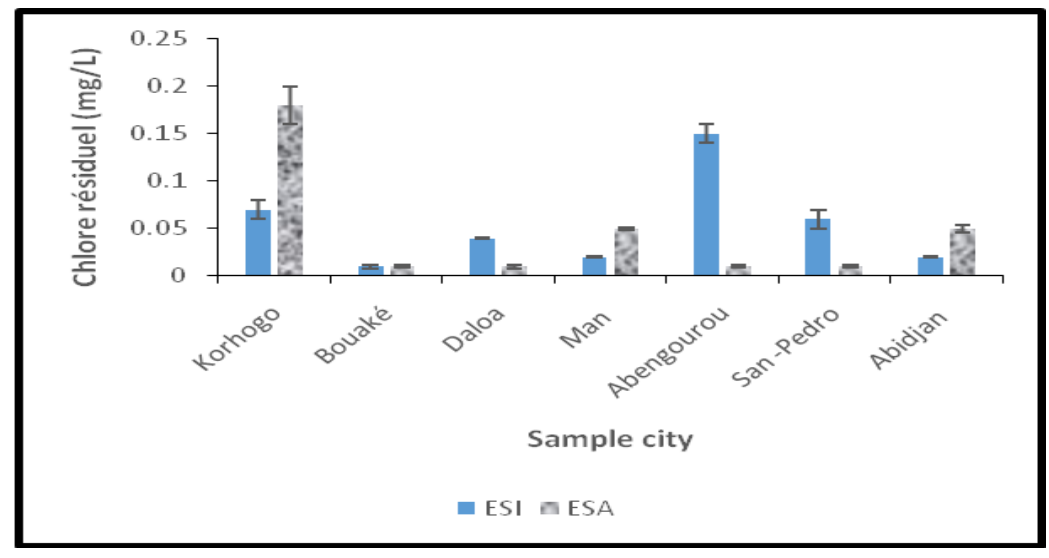

\section{Residual chlorine from bagged water}

Residual chlorine values vary between 0.1 and $0.18 \mathrm{mg} / \mathrm{L}$. The residual chlorine values recorded in the conditioned water of the cities studied are below the limit value recommended by the WHO, which is around $0.2 \mathrm{mg} / \mathrm{L}$ for drinking water. The noncompliance of the residual chlorine values observed in bagged water would be related to the phenomenon of evaporation during the bagging of water. These low chlorine levels could also be due to the exposure of this water to solar radiation. Low levels of residual chlorine were observed by Kouakou et al., (2010), in Andokoi's stored water in Abidjan. They point out that high indoor temperatures promote the evaporation of chlorine.
According to Kahoul and Touhami (2014), chlorine is a gas that evaporates during water storage. Indeed, chlorine prevents the proliferation of most pathogenic microorganisms (Belghiti et al., 2013).

\section{Bacterial load of artisanally packaged water}

Tables 1 and 2 show the bacterial loads of mesophilic aerobic germs, total coliforms of Escherichia Coli and Salmonella Sp. in artisanal and industrial conditioned waters. There is a total absence of Salmonella sp. in both types of conditioned water. It should be pointed out that the levels of contamination of artisanally packaged waters with mesophilic aerobic germs, total coliforms and 
Escherichia Coli are 19.99\%, $17.6 \%$ and $4.7 \%$, respectively. For industrially packaged waters, the contamination levels of these water samples by mesophilic aerobic germs, total coliforms and Escherichia Coli are 14.28, 9.04 and 3.32, respectively. The proliferation of these bacteria in industrially packaged waters could be due to the low residual chlorine values obtained in bagged waters. Indeed, chlorine prevents the proliferation of most microorganisms in water (Belghiti et al., 2013).An analysis of the different types of water reveals that water samples conditioned in an artisanal way are more contaminated than those conditioned in an industrial way. The high contamination of samples of artisanally packaged water could be due to the hygienic conditions during packaging and transport. Indeed, these artisanally packaged waters were packaged by hand. Handling of the water during packaging and transport could lead to the proliferation of bacteria in the water. Hounsounou et al., (2017) state in their work that the various manipulations of water are potential factors in its contamination. Also, according to Ayad, (2017), shows that water can be of good quality at the source, but the hygienic conditions adopted during storage and transport can contribute to the degradation of its quality.

In conclusion this study carried out in the cities of Korhogo, Bouaké, Daloa, Man, Abengourou, San-Pedro allowed to appreciate the quality of water conditioned in a craft and industrial way.

It emerges from this work that the majority of the $\mathrm{pH}$ of the water packaged in bags in these localities are acidic. There is a significant difference between the values of turbidity of water packaged in an artisanal and industrial manner in the cities of Korhogo, Bouaké, Daloa and Abidjan. Temperatures of conditioned water vary between 13.6 and $22.6^{\circ} \mathrm{C}$. The levels of residual chlorine recorded in the conditioned water of the cities studied do not comply with the limit value recommended by the WHO, which is of the order of $0.2 \mathrm{mg} / \mathrm{L}$. Concerning the microbiological quality of the bagged water, the analyses revealed the presence of mesophilic aerobic germs, Total Coliforms and Escherichia Coli. The analyses revealed that the samples of water conditioned in an artisanal way are more contaminated than those conditioned in an industrial way. Therefore, the water packaged in the artisanal and industrial way is not of good quality from a bacteriological point of view.

\section{References}

Akiyo, O. L. R., 2017. Consommation de l'eau en sachet et ses effets socioenvironnementaux dans la Commune de Parakou, International. Journal of Biological and Chemical Sciences. 11(4): 1727-1740.

Ahoussi, E. K., Keumean, N. K., Kouassi, M., A. and Koffi, B., Y., 2018.Etude des caractéristiques hydrogéochimiques et microbiologiques des eaux de consommation de la zone périurbaine de la ville de Man: cas du village de Kpangouin (Côte d'Ivoire), InternationalJournal of Biological and Chemical Sciences, 11(6): 3018-3033.

Belghiti, M., L., Chahlaoui, A., Bengoumi, D.and EL Moustaine, R., 2013. Etude de la qualité physico-chimique et bactériologique des eaux souterraines de la nappe plio-quaternaire dans la région de Meknès (Maroc), Larhyss Journal, 14: 21-36.

Blé,L., O., Soro, T., D., Dje, K., B., Degny, G., S.and Biemi, J., 2015.Eaux conditionnées en sachets: quels risques d'exposition des populations du district d'Abidjan ? Larhyss Journal, 24: 85107. 
Blé, L,. O.and Mahaman, B.,S., 2009. Étude de la Potabilité des Eaux de Boisson Conditionnées en Côte d'Ivoire: Cas des Eaux de la Région du Grand Abidjan. European Journal of Scientific Research, 28(4): 552-558.

El Haissoufi, H., Berrada, S., Merzouki, M., Aabouch, M., Bennani, L., Benlemlih, M., Idir, M., Zanibou A., Bennis, Y.and El Ouali lalami, A. 2011. Pollution des eaux de puits de certains quartiers de la ville de Fès, Maroc, Revue Microbiologie. Industriel Santé et Environnement, 5(1): 37- 68.

Hounsounou, E., O., Tchibozo, M., A.,D., Ayi-Fanou, L. and Agbossou, E., 2017. Chaîne de l'eau du réseau public dans quelques quartiers précaires du sixième arrondissement de Cotonou-Bénin, revue électronique en sciences de l'environnement, 3 (17): 1-18.

Kahoul, M. and Touhami, M., 2014. Évaluation de la qualité physicochimique des eaux de consommation de la ville d'Annaba (Algérie). Larhyss Journal, (19): 129-138.

Kouadio, K., Manizan, N., P., K., Coulibaly J., Toure, M A., A., Dosso E., 2013Risque sanitaire liés a des eaux en sachet plastique vendues dans la ville
d'Abidjan (CÔTE D'IVOIRE), Revue Bio-Africa, 11 : 31-37.

Kouakou., J., G., Oga, S.., Claon, M., Bama, D., Koua, M., Houénou, Y. and Kouadio, L., K. 2012. Conditions d'accès et de stockage de l'eau: enquête dans les ménages en zone périurbaine à Abidjan, Santé publique, 2(24): 133142.

MBra R. K., Koné B., Kouakou É. Y., Silué B., Cissé G. et Soro N.2015. Approvisionnement en eau potable, qualité de la ressource et risques sanitaires associés à Korhogo (NordCôte d'Ivoire). Environ Risque Santé, 142: 30-241.

OMS, 2011.Guideline to Drinking Water Quality (fourth edition). ISBN 97892 41548151 (NLM classification: WA $675), 564 \mathrm{p}$.

ONU, 2019.Rapport sur les perspectives de la population dans le monde 2019: Principaux résultats, $4 \mathrm{p}$.

Ayad, W., 2017. Evaluation de la qualité physico-chimique et bactériologique des eaux souterraines: cas des puits de la région d'El-Harrouch (wilaya de skikda), thèse de doctorat, Université d'Annaba, 116 p.

\section{How to cite this article:}

Kouadio Enika Floresse, N'goran-Aw E. B. Zita, Soro Doudjo, ASSIDJO Nogbou Emmanue. 2020. Evaluation of the Chemical and Bacteriological Quality of Bagged Water in Ivory Coast (Seven Localities). Int.J.Curr.Microbiol.App.Sci. 9(10): 3510-3517. doi: https://doi.org/10.20546/ijcmas.2020.910.405 